\title{
On the compressibility of two layer lateritic soil profile of Vichada region Colombia
}

\author{
Calos Eduardo Torres, MEng ${ }^{1}$, Julio Esteban Colmenares, $\mathrm{PhD}^{2}$ \\ ${ }^{1}$ Universidad Santo Tomás, Bogotá Colombia, carlos.torresr@usantotomas.edu.co \\ ${ }^{2}$ Universidad Nacional de Colombia, Bogotá Colombia, jecolmenaresm@unal.edu.co
}

\begin{abstract}
It is analyzed the influence of microstructure of a lateritic soil profile from Vichada department Colombia, in its compressibility for a KO stress path, in an equipment adapted with piezoceramic transducers, capable of emitting and receiving simultaneous shear and compression waves. For this, oedometric compression tests were performed in samples with different structure conditions, like a natural soil samples, reconstituted, sutured and soils samples in slurry suspension at the liquid limit. It was confirmed that the microstructure in both layers exerts an influence on the volumetric behavior, which is more evident in the upper horizon and is related to the strongest weathering intensity. The Vichada department is characterized by having a road network in poor condition due to the generalized ignorance of the behavior of soils in the region. The results presented in the article are an advance in the state of the art of the study of mechanical behavior in Colombian lateritic soils.
\end{abstract}

Keywords-compressibility, lateritic soil, oedometric, stiffness

\section{INTRODUCTION}

Authors such as [1], [2] and [3] have framed the study of structured soils from the analysis of the compressibility curve under different structure conditions for the same water content. The use of this logarithmic scale graph in soil mechanics arises from the fact that the virgin compression curve of a sedimentary soil is approximately linear when represented by a logarithmic scale on the stress axis. However, the residual soils in their genesis were not subjected to a process of sedimentation and consolidation, and they do not have a virgin compression line, so that analyzing the compressible behavior in logarithmic scale can lead to serious errors in the understanding and interpretation of the compressibility characteristics of residual soils [4]. For this reason the compressibility curves are presented in logarithmic and arithmetic scales.

\section{SOILS PROFILE}

The Vichada department is located in the eastern region of Colombia, on the left bank of the Orinoco River and on the right bank of the Meta River. The municipality of Cumaribo has temperatures between $18^{\circ}$ and $36^{\circ} \mathrm{C}$, rainfall between 1,500 and 2,540 $\mathrm{mm} /$ year with maximum rains from April to September and minimums from February to March [5]. The soil profile is composed of two layers. The upper layer reaches a depth of $0.75 \mathrm{~m}$ and is composed of clays of high plasticity, of yellow to reddish color, of medium consistency. The lower layer is composed of clay and silt of high plasticity, reddish color and medium to high consistency. In the Fig. 1 shows the soil profile studied.

Digital Object Identifier (DOI):

http://dx.doi.org/10.18687/LACCEI2019.1.1.333

ISBN: 978-0-9993443-6-1 ISSN: 2414-6390
The main components of lower horizon are quartz, clay minerals and gibbsite, which associated with iron hydroxides. The horizon 2 has a higher illite content and a lower kaolinite content, compared to the horizon 1 , which is associated with the fact that horizon 1 has been more affected by the weathering processes [6].

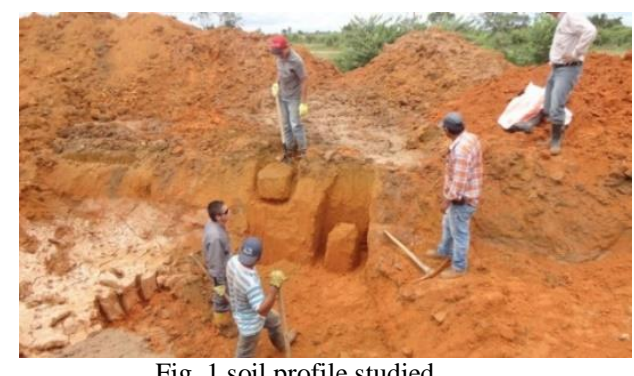

Fig. 1 soil profile studied

\section{DIFFERENT SOIL STRUCTURE CONDITIONS}

Recent studies ( [7], [8], [9] and [10]) have shown that the mechanical behavior and stiffness of residual soils depends on the pedogenetic processes that gave rise to them, and therefore its micro structure conditions. In order to study this effect, the behavior of natural soils is compared with that of remoulded and compacted samples at different densities and water contents. From these new states, in which the microstructure was removed and conditions were modified at the fabric level, the influence it exerts on mechanical behavior and stiffness can be studied. The soil structure conditions that were studied are described below:

A Natural Condition (N): The first behavior analyzed is the materials under natural conditions (the samples in this state are designated with the prefix "N"). This condition is the frame to determine the influence of the microstructure on the mechanical behavior of the soil profile. To study this state, samples were directly carved from the blocks of unaltered material, and were tested without flooding the cell (partially saturated to their initial water content), in order not to remove or alter the cementing bonds and suction.

B. Compacted condition to natural density (D): By remodeling of natural samples of the two horizons, specimens without structure are obtained. This soil, to which the cementing component was removed, is brought by static compaction to its natural or initial volumetric state (water content, density and void ratio). In this way, soil behavior is obtained in two scenarios, for the same initial conditions:

$17^{\text {th }}$ LACCEI International Multi-Conference for Engineering, Education, and Technology: "Industry, Innovation, And Infrastructure for Sustainable Cities and Communities", 24-26 July 2019, Jamaica. 
behavior with and without structure. In the same way, the samples are tested without flooding the oedometric cell.

C. Compacted condition to maximum density (C): From remoulded soil (without structure), samples were prepared with a density equivalent to the maximum density of the standard Proctor test, and water content equivalent to the optimum water content obtained from the proctor test. This condition represents the structural state of a road fill or embankment, and it is estimated to be the best geometric arrangement or packing that the soil can have at the fabric level. With the analysis of this condition, the effect of soil improvement by compaction was studied, after the structure had been removed, compared to the one presented by the material under natural conditions.

D. Reconstituted Condition (SL): An additional condition was that of reconstituted soils from a suspension to the liquid limit or "slurry". This state was evaluated to determine the space allowable by the microstructure in the mechanical behavior of the soil profile. [3] determined that this permissible space is located between the curve of the material in suspension (slurry) and that of the soil in its natural state, so that having these two behaviors, it was possible to confirm the influence exerted by the microstructure in the mechanical behavior and stiffness of the soil profile. This condition generates the loosest fabric possible of the material without structure, with respect to the other states analyzed.

E. Natural sample in Condition of total saturation (SA): Finally, we studied the most critical condition of the mechanical behavior of the lateritic soils of Vichada, which turns out to be the total saturation. For this, unaltered samples (carved directly from the block) were taken and tested under saturated conditions (flooding the oedometric cell throughout the test). With this, any contribution of the suction to the mechanical behavior is removed, thus determining the combined effect of the suction and the degradation of the cementing bonds.

The initial conditions of all the samples are presented in TABLE I. The prefix used designates the structural condition, and the number corresponds to the layer or horizon analyzed.

TABLE I

Soil samples analyzed

\begin{tabular}{|c|c|c|c|c|c|c|}
\hline Sample & Test condition & $\begin{array}{l}\mathrm{W} \\
(\%)\end{array}$ & $\gamma \mathrm{t}\left(\mathrm{kN} / \mathrm{m}^{3}\right)$ & $\gamma \mathrm{d}\left(\mathrm{kN} / \mathrm{m}^{3}\right)$ & $\mathrm{e}_{0}$ & $\begin{array}{c}\mathrm{S} \\
(\%)\end{array}$ \\
\hline N1 & $\begin{array}{l}\text { Natural State, corresponding to horizon } 1 \text { and tested partially } \\
\text { saturated. }\end{array}$ & 32.56 & 17.00 & 12.82 & 1.18 & 76.99 \\
\hline $\mathrm{N} 2$ & $\begin{array}{l}\text { Natural State, corresponding to horizon } 2 \text { and tested partially } \\
\text { saturated. }\end{array}$ & 35.83 & 16.90 & 12.44 & 1.24 & 80.33 \\
\hline D1 & $\begin{array}{l}\text { Compacted condition to natural density, corresponding to } \\
\text { horizon } 1 \text { and tested partially saturated. }\end{array}$ & 32.56 & 17.50 & 13.20 & 1.11 & 81.84 \\
\hline D2 & $\begin{array}{l}\text { Compacted condition to natural density, corresponding to } \\
\text { horizon } 2 \text { and tested partially saturated. }\end{array}$ & 33.97 & 16.60 & 12.39 & 1.24 & 76.16 \\
\hline $\mathrm{C} 1$ & $\begin{array}{l}\text { Compacted to maximum density. Horizon 1. Tested partially } \\
\text { saturated. }\end{array}$ & 22.40 & 19.70 & 16.09 & 0.73 & 85.61 \\
\hline $\mathrm{C} 2$ & $\begin{array}{l}\text { Compacted to maximum density. Horizon } 2 \text { Tested partially } \\
\text { saturated. }\end{array}$ & 23.30 & 18.67 & 15.14 & 0.84 & 77.11 \\
\hline SL1 & Suspension prepared from the liquid limit. Horizon 1. & 60.00 & 17.00 & 10.63 & 1.63 & 102.70 \\
\hline SL2 & Suspension prepared from the liquid limit. Horizon 2. & 63.00 & 16.90 & 10.37 & 1.69 & 103.63 \\
\hline SA1 & $\begin{array}{l}\text { Unaltered condition, corresponding to horizon } 1 \text { and tested in } \\
\text { a state of total saturation. }\end{array}$ & 32.56 & 17.50 & 13.20 & 1.12 & 100.0 \\
\hline $\mathrm{SA} 2$ & $\begin{array}{l}\text { Unaltered condition, corresponding to horizon } 2 \text { and tested in } \\
\text { a state of total saturation. }\end{array}$ & 35.83 & 17.00 & 12.52 & 1.23 & 100.0 \\
\hline
\end{tabular}

Conventions:

w (\%): $\quad$ water content

$\gamma \mathrm{t}(\mathrm{kN} / \mathrm{m} 3): \quad$ Total unit weight

$\gamma \mathrm{d}(\mathrm{kN} / \mathrm{m} 3)$ : $\quad$ Dry unit weight

e0: $\quad$ Initial void ratio

S (\%): $\quad$ Degree of saturation

\section{NATURAL CONDITION}

The first soil condition studied is by the unaltered (natural) samples, whose curve represents that of the structured material for the natural water content, and is the starting point for comparing any other volumetric and structural state.
Fig. 2 shows the compressibility curve for the two layers, elaborated from undisturbed samples and tested in partial saturation condition, to the natural water content and suction. The water content and saturation for the two levels were reported in TABLE I

Different from sedimentary soils, the initial void relationship of structured materials does not have a direct relationship with the in situ stress, therefore, the yielding

$17^{\text {th }}$ LACCEI International Multi-Conference for Engineering, Education, and Technology: "Industry, Innovation, And Infrastructure for Sustainable Cities and Communities", 24-26 July 2019, Jamaica. 
stress are related to the microstructure provided by the weathering processes [9]; however, the compressibility curve of Fig. 2 shows the fact that both layers, starting from different volumetric states, with a higher void ratio for the less altered material (lower - N2), end in a volumetric state very similar (final void ratio), which shows that the upper level has a more stiff structure that provides less compressibility.
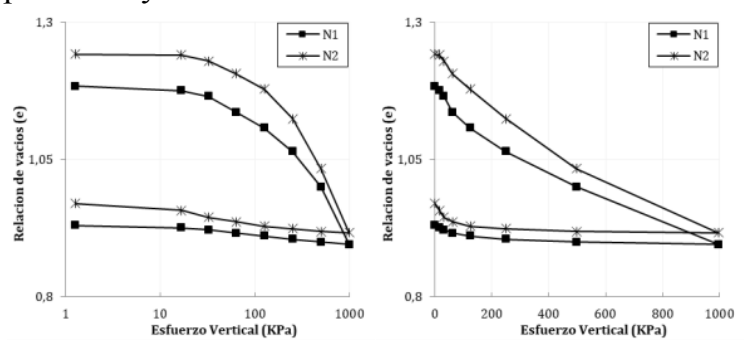

Fig. 2 compressibility curves in the natural state for the two horizons

Fig. 2 shows a change in the slope for a stress value close to $32.5 \mathrm{kPa}$, which is designated as the pre-yield or initial yield, which occurs before to the yield stress of the structured material [11]. In both cases, the materials show a strain hardening associated with the increase in density and stiffness with vertical stress, which [4] mentions as typical of dense soils with a low liquidity index, being the case of the two levels of the soil profile studied and typical of lateritic soils.

\section{PERMISSIBLE SPACE FOR THE STRUCTURE}

Since the existence of a cemented microstructure that influences the resistance and stiffness characteristics of the two natural soil horizons was confirmed, the characteristics of this microstructure and the space allowable by it are also studied. From soil without structure (prepared with natural remoulding material), and taken to the volumetric state of the natural condition (comparing it to the water content and initial or unchanged density), the behavior was obtained for a condition in which the microstructure does not contribute to stiffness. Additionally, these two behaviors are compared (with and without structure), with the one that presents the material in suspension to the liquid limit (slurry); curve that demarcates the space allowable by the structure and corresponds to the behavior for the most loose condition possible at the fabric level.

The mechanical behavior of residual soils formed from a slurry suspension is comparable to that exhibited by sedimentary soils during re-sedimentation processes, behavior known as virgin or intrinsic compression [2]; However, the genesis of the residual soils is not associated with sedimentation processes, so the compressibility in this state of suspension serves as a tool to determine if the soil structure influences the mechanical behavior, but not to treat to replicate processes associated with the genesis of materials.
The compressibility curve for horizon 1 is presented in Fig. 3. The difference in behavior for the natural (N1) and unstructured or compacted to natural density (D1) states is obvious, even though both started from the same initial condition, which shows the influence exerted by the microstructure on the mechanical behavior of this horizon. On the other hand, the curve of the material in slurry suspension, marks the space allowed by the structure. This curve (SL1) is aligned with that of the unstructured material (D1), after the yield stress for the unstructured condition is reached, close to a value of $60 \mathrm{kPa}$. From this stress value, the compressibility increases remarkably.
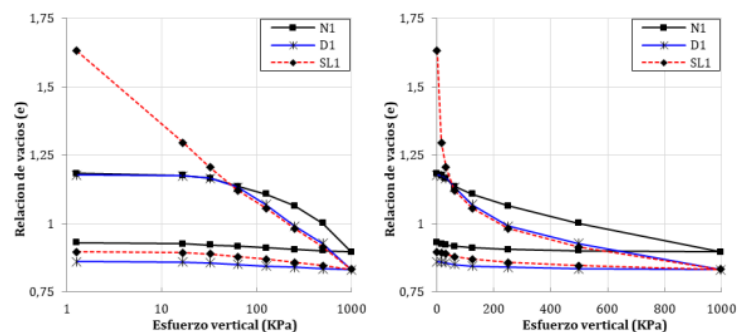

Fig. 3 compressibility curve for horizon 2 in natural condition $(\mathrm{N})$, without structure (D) and in suspension at liquid limit (SL)

Fig. 4 shows the compressibility curves for horizon 2 . The soil in natural state (N2) has the same shape and slope of the compacted state at natural density (D2), which indicates that the microstructure in this case does not significantly influence the mechanical behavior. It is also observed that at this layer, all the states converge to the same behavior, for a stress close to $250 \mathrm{kPa}$, a value that turns out to be higher than the one found for horizon 1 . This value coincides with the level of stress at which they took the unstructured samples (D2) by static compaction, whose curve is presented in Fig. 5.
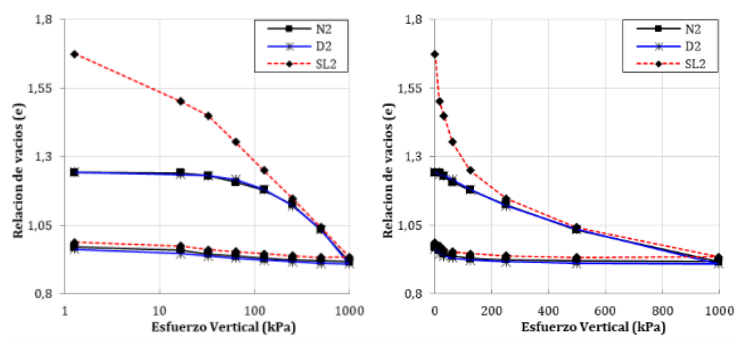

Fig. 4 compressibility curve for horizon 1 in natural condition ( $N$ ), without structure (D) and in suspension at liquid limit (SL))

$17^{\text {th }}$ LACCEI International Multi-Conference for Engineering, Education, and Technology: "Industry, Innovation, And Infrastructure for Sustainable Cities and Communities", 24-26 July 2019, Jamaica. 


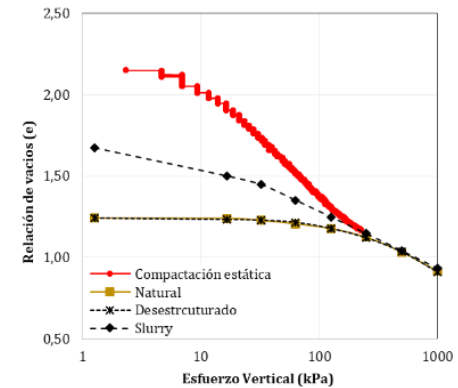

Fig. 5 static compaction curve for upper horizon

\section{OEDOMETRIC MODULE}

To establish differences in the mechanical behavior of the two horizons of the soil profile, the variation of the oedometric module with vertical stress is presented in Fig. 6. In horizon 1 (Fig. 6-A) the difference in the behavior of the soil in natural state with respect to the unstructured is evident, which does not happen in horizon 2 (Fig. 6-B), because is observed that both states with and without structure have a similar behavior. The unstructured condition of the upper horizon is aligned with the curve of the material in suspension to the liquid limit, which confirms the fact that the microstructure at this level is the one that provides it with greater stiffness and resistance.
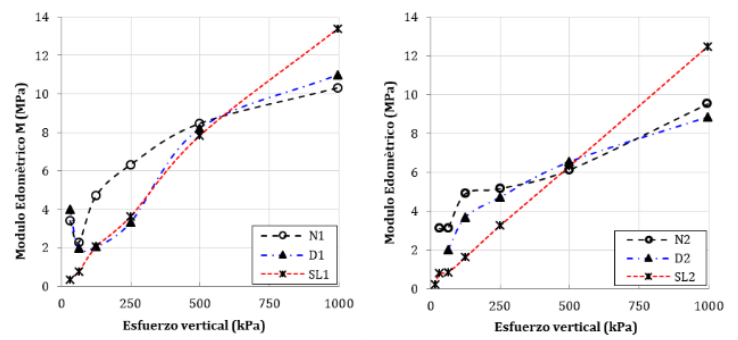

Fig. 6 variation of the oedometric module with vertical stress

The upper horizon registers a greater stiffness compared to the lower horizon in its natural state. Additionally, it is observed that when removing any vestige of the microstructure by remolding and subsequent reconstitution, there is a notable reduction in the stiffness for the horizon 1 , which is not so evident in the less second horizon, because it does not have such a significant contribution from the weathering processes. [9] Found that the allowable space for the structure from the analysis of the oedometric module is located above the $\mathrm{M}_{\text {oedn }} / \mathrm{M}_{\text {oedc }}=1$ ratio, with the numerator being the module in natural conditions and the denominator in a destructured condition. This same analysis was carried out for materials with and without structure in the two horizons, and the results are presented in Fig. 7.

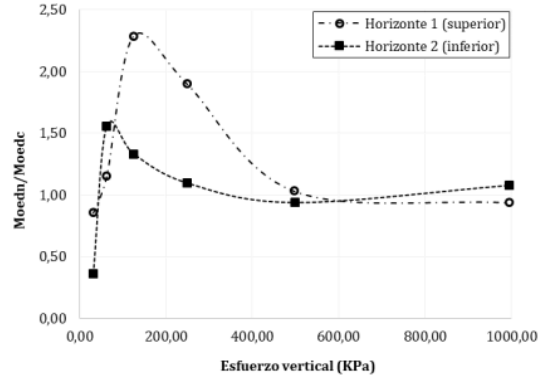

Fig. 7 edometrics modules ratio analysis

It is observed that both soil layers start from values lower than 1.0; however, the upper horizon registers a module ratio very close to the unit $\left(\mathrm{M}_{\text {oedn }} / \mathrm{M}_{\text {oedc }}=0.83\right)$, which confirms the greater stiffness of this level compared to the underlying one.

The fact that the lower horizon presents greater stiffness in the unstructured condition compared to the natural one, is associated to the microstructure does not exert a great influence on the mechanical behavior of this level, and also to the initial stress condition that was induced by the process of reconformation by static compaction.

For stress greater than $30 \mathrm{kPa}$; value close to the condition of in situ stresses, it is observed that the stiffness in the natural state is greater than material without structure in the two soil levels, being more evident in the upper layer. For a stress value of $125 \mathrm{kPa}$, a change in the slope of the curve for horizon 1 is observed, which is associated with the degradation of the microstructure and was identified as the yield stress of the structured materials. Finally, it is observed that for stress close to $500 \mathrm{kPa}$, the material in its natural state present a reduction in stiffness below the unstructured material and that is when all the volumetric states converge to the same condition.

\section{VARIATION OF STRUCTURE CONDITIONS}

It's analized the effect of two (2) physical processes that commonly occur in the lateritic soils of the Vichada department and that have a direct influence on their structure conditions and stiffness. The first one is compaction at maximum dry density; process that occurs when road fillings or embankments are made from natural material; which is remolded, dried and brought to the optimum water content and then compacted. The second process is saturation, which occurs during high precipitation events, usually long and of low intensity. The soil profile is characterized by having a cemented microstructure and being in a condition of partial saturation, so that the action of water is the factor that most alters the stiffness and resistance characteristics of the two horizons.

$17^{\text {th }}$ LACCEI International Multi-Conference for Engineering, Education, and Technology: "Industry, Innovation, And 
The compacted samples at maximum density, were prepared from natural material, which was remoulded and then statically compacted to the optimum water content obtained from the standard proctor test. On the other hand, the saturated samples were obtained by directly carving unaltered specimens from the block, which were tested in oedometric compression, but with full saturation during the whole test.

Fig. 8 shows the compressibility curves for horizon 1 (upper), in natural (N1), compacted at maximum dry density (C1) and full saturation (SA1) condition. It is observed that the two different conditions from the natural modify the compressible behavior of the soil. In the case of saturation, the increase in compressibility is notable, although both materials (natural and saturated), start from the same initial structure conditions. The stiffness decrease immediately; nevertheless, the initial pre-yield or yielding stress continues to be close to $40 \mathrm{kPa}$. The water exerts a notorious effect in the dissolution of the cementing component, taking the material to a state in which the microstructure no longer contributes to the stiffness, for stress superior to the pre-yielding one. In the same way, the total saturation removes the contribution of the suction to the resistance, which means an immediate decrease in the stiffness in this condition.

In the compacted state (C1) the first effect observed is the reduction in the initial void ratio. The range in which the pre-yield stress occurs is also maintained in this compacted state, which denotes that this process occurs at the fabric level without involving even the degradation of the microstructure, which is consistent with [12] says, who suggests that this primary yield has an elastic component and occurs for lesser stress than the structure yielding.
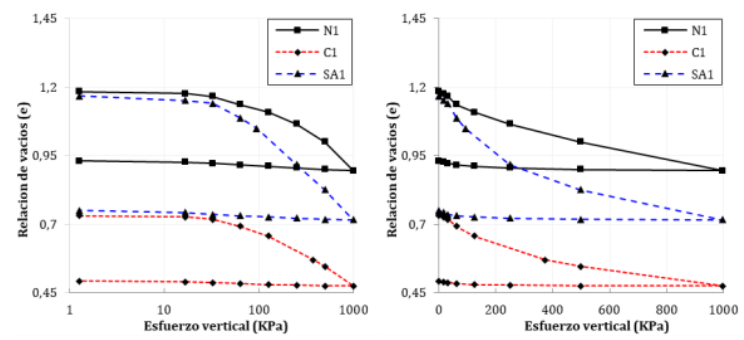

Fig. 8 compressibility curves in the natural, compacted and saturated state for upper horizon

Fig. 9 shows the compressibility curves for horizon 2 under natural $(\mathrm{N})$, compacted $(\mathrm{C})$ and saturated (SA) condition. In this horizon the increase in compressibility for the saturated condition is more evident. The difference in the volumetric deformations to the natural state, are given for the first increase in stress. The fact that it is more susceptible to the effect of saturation is related to a weaker microstructure than the upper layer, and to the higher water content in the natural state that this layer presents, which implies less suction contributing to the stiffness. In this condition, a single yielding stress is identified, due to the fact that the microstructural component in this horizon has no influence on the stiffness. This fact was made clear in the previous section when the two horizons were compared in their natural state.

The water influence degrades even the properties of compacted materials, which is clearly visible in the Vichada department along roads where lateritic soils were used to form road embankments. In Photograph 52 the before and after the roads in the department are presented, after precipitation events occur and the materials are saturated.
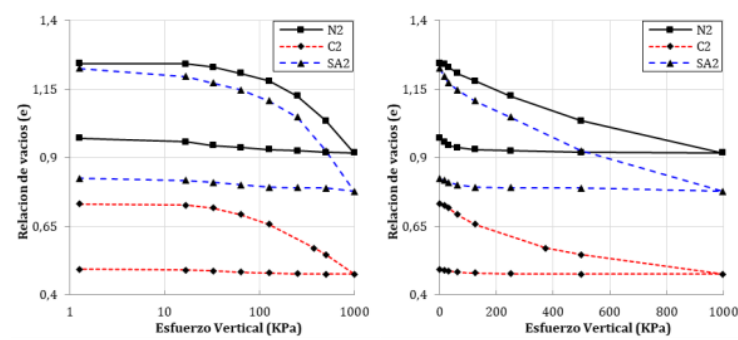

Fig. 9 compressibility curves in the natural, compacted and saturated state for lower horizon

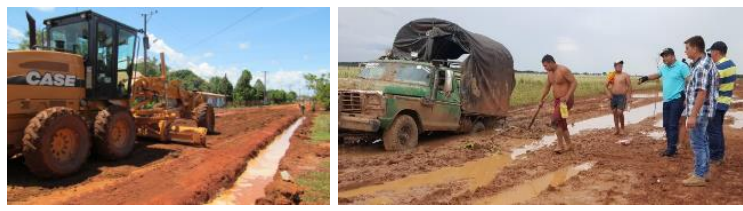

Fig. 10 Before and after the rain in the construction of an embankment [13].

In the compacted condition for the horizon 2 (C2), the first effect observed is the decrease of the initial void ratio. In this case, a steeper change in the slope of the curve in logarithmic scale is perceived, for the level of stress called as initial yield (between $40 \mathrm{kPa}$ and $60 \mathrm{kPa}$ ), and as for the saturated soil, this turns out to be the only yield stress that can be identified in horizon 2, under the structure conditions analyzed.

A similar result was reported by [1] in Brazil's lateritic soils, finding that the unaltered material registers a better mechanical behavior compared to it after being remolded (compacted to natural density). He also found that the curve of the destructured material is aligned with the sample in suspension, and finally showed that the mechanical behavior of lateritic soils compacted at maximum density turns out to be below that of the soil in its natural state.

Fig. 11 shows the variation of the oedometric module for the natural $(\mathrm{N})$, saturated $(\mathrm{SA})$ and compacted

$17^{\text {th }}$ LACCEI International Multi-Conference for Engineering, Education, and Technology: "Industry, Innovation, And Infrastructure for Sustainable Cities and Communities", 24-26 July 2019, Jamaica. 
conditions at maximum density (C), for the two horizons of the soil profile. The slurry state (SL) is also plotted, as a reference for the loosest possible state of the soil without structure. The differences in the behavior of the two horizons of the profile are notable. In the case of horizon 1 (Fig. 11- A), it is observed that the compacted and saturated states differ considerably from the natural condition; nevertheless, the same initial yield stress is perceived in the three conditions (close to $40 \mathrm{kPa}$ ), associated, as has already been said, with the presence of a cemented microstructure.

On the other hand, in horizon 2 (Fig. 11- B) it is observed that the saturated and compacted condition have a similarity behavior of natural soil near to $250 \mathrm{kPa}$ stress value, at which point irreversible changes occur in the soil structure.
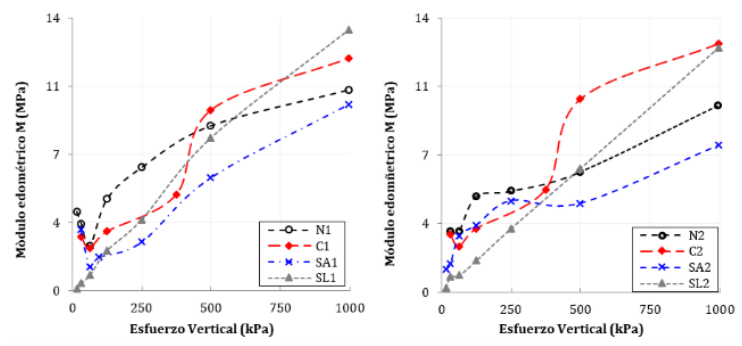

Fig. 11 oedometric module for two layers in natural $(\mathrm{N})$, compacted $(\mathrm{C})$, sutured and slurry suspension (SL)

From the analysis of the different structure conditions, relevant aspects can be extracted in terms of the influence of weathering processes on the mechanical behavior and the stiffness of the soil profile. These aspects are detailed in TABLE II.

TABLE II

Conclusions of the compressibility analysis of the two horizons

\begin{tabular}{|c|c|c|}
\hline $\begin{array}{l}\text { Condition } \\
\text { analyzed }\end{array}$ & Horizon 1 (upper) & Horizon 2 (lower) \\
\hline $\begin{array}{l}\text { Natural } \\
\text { state. }\end{array}$ & $\begin{array}{l}\text { - } \text { Greater stiffness } \\
\text { compared to the } \\
\text { underlying horizon } \\
\text { - Mechanical behavior } \\
\text { strongly influenced by } \\
\text { the cemented } \\
\text { microstructure. } \\
\text { - It is possible to identify } \\
\text { the space allowed by the } \\
\text { structure. }\end{array}$ & $\begin{array}{l}\text { - Less stiffness compared } \\
\text { with the upper layer. } \\
\text { - Little influence of the } \\
\text { microstructure on the } \\
\text { mechanical behavior. }\end{array}$ \\
\hline $\begin{array}{l}\text { Compacted } \\
\text { to natural } \\
\text { density }\end{array}$ & $\begin{array}{l}\text { - The stiffness decreases } \\
\text { compared to the natural } \\
\text { state. } \\
\text { - A single yielding stress } \\
\text { is identified. }\end{array}$ & $\begin{array}{l}\text { - There are no substantial } \\
\text { differences in behavior } \\
\text { with and without } \\
\text { structure. }\end{array}$ \\
\hline $\begin{array}{l}\text { Compacted } \\
\text { to } \\
\text { maximum } \\
\text { density }\end{array}$ & $\begin{array}{l}\text { - The initial stiffness is } \\
\text { lower than in the natural } \\
\text { state, despite the } \\
\text { increased compactness. } \\
\text { - Two yield stresses are } \\
\text { identified, and the first } \\
\text { coincides with the initial }\end{array}$ & $\begin{array}{l}\text { - The stiffness is lower } \\
\text { than in the natural state. } \\
\text { After the yield, the } \\
\text { oedometric module } \\
\text { increases proportionally } \\
\text { with the density of the } \\
\text { material. }\end{array}$ \\
\hline
\end{tabular}

\begin{tabular}{|c|c|c|}
\hline Condition & Horizon 1 (upper) & Horizon 2 (lower) \\
\hline & $\begin{array}{l}\text { yield stress associated } \\
\text { with the microstructure. }\end{array}$ & \\
\hline $\begin{array}{l}\text { Natural } \\
\text { condition } \\
\text { tested } \\
\text { saturated }\end{array}$ & $\begin{array}{l}\text { - There is an initial } \\
\text { decrease in stiffness, } \\
\text { associated with the loss } \\
\text { of suction, and the } \\
\text { second is associated with } \\
\text { the degradation of the } \\
\text { microstructure. } \\
\text { - This state results to have } \\
\text { a lower stiffness than the } \\
\text { reconstituted material. } \\
\text { The yield stress } \\
\text { coincides with the initial } \\
\text { yield attributed to the } \\
\text { microstructure. }\end{array}$ & $\begin{array}{l}\text { - The initial decrease is } \\
\text { identified due to the loss } \\
\text { of the suction, but then } \\
\text { the stiffness is recovered } \\
\text { until the natural state is } \\
\text { equalized. } \\
\text { - The yield stress } \\
\text { coincides with that of the } \\
\text { material in its natural } \\
\text { state, but the decrease in } \\
\text { stiffness is greater in this } \\
\text { condition. }\end{array}$ \\
\hline
\end{tabular}

\section{CONCLUSIONS}

The upper horizon in the natural state is less compressible than the underlying, since both have similar water contents and initial void ratios, this due to the distinctive microstructure conditions derived from the weathering processes, more advanced in the upper layer.

The two horizons present an initial yield stress (preyield) associated to the suction and the interaction between the mineral clasts, without the degradation of the microstructure conditions, and then a yielding stress when the cementing bonds disintegrate. When cementing is removed, a notable increase in compressibility is recorded and the pre-yield stress disappears, which does not happen with horizon 2 , since the condition with and without structure presents a similar and little differentiable volumetric behavior.

Compaction at maximum dry density improves the conditions at the fabric level of unstructured materials. For low levels of stress, the soil in natural state turns out to be less compressible than the material compacted to maximum density, which is associated with the presence of the cementing bonds. This behavior is clear in the most altered (upper) horizon, and little differentiable in the underlying, less influenced by the microstructure.

When the soil is saturated, there is an increase in compressibility for two levels of stress: first, immediately due to the absence of suction as a contribution to stiffness, which is observed as a reduction in the voids ratio without change in the slopes of the curve; and second, after the yield stress, when the microstructure is completely degraded by the action of water. The lower horizon is more compressible in its natural state and its behavior in saturated and partially saturated conditions is very similar, given the larger pore size and lower suction, associated with a high water content in natural condition.

$17^{\text {th }}$ LACCEI International Multi-Conference for Engineering, Education, and Technology: "Industry, Innovation, And Infrastructure for Sustainable Cities and Communities", 24-26 July 2019, Jamaica. 
It was confirmed that the microstructure in both layers exerts an influence on the volumetric behavior, which is more evident in the upper horizon. The space allowed by the microstructure is located between the curve of the material in its natural state, and the slurry suspension. The stress level that frames this space is located after the preyield stress (40kPa to $60 \mathrm{kPa}$ ) to a $450 \mathrm{kPa}$ and $500 \mathrm{kPa}$ stress value, where all microstructural effects are removed in both horizons.

\section{References}

[1] M. (. Vargas, "Some engineering properties of residual clay soils occurring in southern Brazil.," International conference on soil mechanics and foundation engineering (vol. 3)., pp. 67-71, 1953.

[2] J. B. Burland, " On the compressibility and shear strength of natural clays.," Géotechnique, 40(3), pp. 329-378, 1990.

[3] S. Leroueil and P. R. Vaughan, "The general and congruent effects of structure in natural soils and weak rocks.," Géotechnique, 40(3), pp. 467-488., 1990.

[4] L. D. Wesley, Geotechnical engineering in residual soils, John Wiley \& Sons., 2010.

[5] C. Torres, Influencia de la microestructura en la rigidez máxima de un perfil de suelo residual en condiciones edométricas. Tesis de Maestría, Bogotá: Universidad Nacional de Colombia, 2017.

[6] J. E. Colmenares, C. E. Torres and G. R. Pérez, "Influence of the suction and microstructure on the stiffness of alateritic soils profile in Vichada department," in XVI CONGRESO COLOMBIANO DE GEOTECNIA, INFRAESTRUCTURA Y RIESGOS GEOTÉCNICOS, Paipa, Boyacá, 2018.

[7] I. F. Otalvaro, M. R. Villarraga and F. J. Nanclares, "Caracterización de la respuesta dinámica de sitio en el Gabro de Medellín.," Revista Ingenierías Universidad de Medellín, 7(13),, pp. 57-69, 2008.

[8] D. Rivas, Influencia de la microestructura en el comportamiento dinámico de los suelos residuales de esquistos en Sabaneta. Tesis de maestria, Medellin: Universidad Nacional de Colombia., 2010.

[9] J. A. Pineda, Influencia de la meteorizacion en el comportamiento mecanico y la rigidez a pequeñas deformaciones de un conjunto de suelos residuales derivados de una granodiorita, Bogotá: Universidad Nacional de Colombia, 2011.

[10] C. Torres and J. E. Colmenares, "Influence of Confining Stress on the Small Strain Stiffness of a Residual Soil under K0 Conditions," in PanAm Unsaturated Soils 2017, Dallas, Texas, 2018.

[11] P. Vaughan, "Keynote paper: Characterising the mechanical properties of in-situ residual soil.," Geomechanics in tropical soils. Proceedings of the

Digital Object Identifier: (to be inserted by LACCEI).

ISSN, ISBN: (to be inserted by LACCEI).

$17^{\text {th }}$ LACCEI International Multi-Conference for Engineering, Education, and Technology: "Industry, Innovation, And Infrastructure for Sustainable Cities and Communities", 24-26 July 2019, Jamaica. second international conference on geomechanics in tropical soils, pp. 469-487, 1988.

[12] P. R. Vaughan, M. Maccarini and S. M. Mokhtar, "Indexing the engineering properties of residual soil," Quarterly Journal of Engineering Geology and Hydrogeology, 21(1), pp. 69-84, 1988.

[13] I. Militares, "Ingenieros Militares," 01 2016. [Online]. Available: https://ingenierosmilitaresdecolombia.wordpress.com/. 